\title{
Women of Ireland, from economic prosperity to austere times: who cares?
}

Marie-Jeanne Da Col Richert

\section{(2) OpenEdition}

Journals

Electronic version

URL: https://journals.openedition.org/etudesirlandaises/3112

DOI: 10.4000/etudesirlandaises.3112

ISSN: 2259-8863

Publisher

Presses universitaires de Caen

Printed version

Date of publication: 30 October 2012

Number of pages: 19-32

ISBN: 978-7535-2158-2

ISSN: 0183-973X

\section{Electronic reference}

Marie-Jeanne Da Col Richert, "Women of Ireland, from economic prosperity to austere times: who cares?", Études irlandaises [Online], 37-2 | 2012, Online since 30 October 2014, connection on 31 July 2022. URL: http://journals.openedition.org/etudesirlandaises/3112 ; DOI: https://doi.org/10.4000/ etudesirlandaises.3112

This text was automatically generated on 31 July 2022

\section{(c)}

Creative Commons - Attribution-NonCommercial-ShareAlike 4.0 International - CC BY-NC-SA 4.0 https://creativecommons.org/licenses/by-nc-sa/4.0/ 


\title{
Women of Ireland, from economic prosperity to austere times: who cares?
}

\author{
Marie-Jeanne Da Col Richert
}

1 The Irish economy flourished from the mid-nineteen nineties until the banking crisis, although there was a short downturn at the beginning of this century; the economic boom benefited employment and brought back outsiders, Irish nationals at first, followed by asylum seekers, and immigrants from outside the EU. Then, as a result of the 2004 and $2007 \mathrm{EU}$ enlargement treaties, the Celtic Tiger ${ }^{1}$ mainly attracted young men and women from the new member states, Polish migrants outnumbering the others $^{2}$. The first part analyses the effects of the new immigration phenomenon on Irish society, with a focus on the relationships between Irish women and female migrants in care work. The way the downturn has hit women, causing the number of female migrants to fluctuate, is also studied. The second part deals with measures adopted to face the financial problems and shows how budget cuts imposed by the government have had specific effects on affected women, in employment in particular, be they nationals or non-nationals ${ }^{3}$ to adopt a recent terminology. The last part of this paper examines ad hoc initiatives in favour of Irish women and migrants. The limits of their action are also brought out. What impact have the last fifteen years brought to bear on women's living conditions, on their status in Irish society? What new social issues have emerged?

\section{Irish women's careers, migrants as carers.}

2 Neoliberal policies of the Celtic Tiger years witnessed the rapid development of economic activity in Ireland; Irish women, whose participation in the workforce had been growing since the 1970s, increased their presence mostly in sectors typical of women's caring role in society: education, health and other administrative and support activities $^{4}$. From the mid 1990s on, women also benefited from job creations mainly in 
the banking, financial and insurance sectors. A category of educated professional young women emerged, who were confronted with the difficulties of combining job and family duties. The editor of a book on migration and domestic work in Europe, Helma Lutz, a German researcher, emphasizes the caring role of migrant women in the family sphere, the particular aspects of a labour market meeting the needs of professional middle-class women who want "to combine gainful employment and care work ${ }^{5 \text { ". While }}$ Ireland is outside of the scope of this book, domestic work performed by migrants nonetheless developed during the Celtic Tiger. The emergence of a new "servant culture" resulted from the social changes that women's mass employment and the arrival of foreign workers generated. Tens of thousands came in a matter of years, a majority of men at first, then an increasing proportion of women ${ }^{7}$. Ireland allowed migrants from the EU-10 accession states free access to its labour market ${ }^{8}$. Female migrants got jobs as domestic workers to perform daily chores, mind children and/or elderly relatives, in "nouveau riche" Irish homes, to quote a derogatory expression used by Labour leader Pat Rabbitte. The exploitation of this new category of employees, in some well off "homes of Celtic Tiger families" has been exposed. It is a new social issue in Ireland, involving both EU and non-EU female migrants ${ }^{10}$, among them illegal migrants below $18^{11}$. Yet, policing is made difficult because the private sphere is not easily accessible to labour inspections, a point developed in a research paper, published in 2009, providing a perspective on care work in the Irish informal or "grey" economy ${ }^{12}$.

3 The feminized health employment sector, where the percentage of non-Irish nationals has increased from 2 to 8 per cent between 1998 and $2004^{13}$, reaching $16.5 \%$ in $2006^{14}$, also provides examples of female migrants' victimization by their Irish colleagues ${ }^{15}$. In the Older Adult Health and Social Care Sector, one third of the care workers are migrants from India, the Philippines and Poland, which is unlikely to change with the economic recession, because the sector is "unregulated and poorly paid ${ }^{16 "}$ and not attractive. According to a study, carried out by the Royal College of Surgeons in Ireland in 2010, in which only non-EU migrant nurses were surveyed, half had experienced disrespect at the workplace, bullying by Irish colleagues or discrimination by nurse management ${ }^{17}$.

These negative aspects of work relationships between female migrant and Irish staff, in the health sector, disclose social realities that have emerged in the country in the past decade ${ }^{18}$. Yet, "by comparison with other European countries, the indigenous population in Ireland is reasonably open to and tolerant of migrants", a conclusion drawn by ESRI researchers from the European Social Survey 2003, before Eastern Europeans from EU-10 and EU-12 member states arrived in Ireland ${ }^{19}$. Such immigration flows then triggered xenophobic reactions, a point developed in a recent article by Grainne O'Keeffe Vigneron ${ }^{20}$.

5 By 2010, the crisis had generated a sharp decline in the number of migrants from Eastern Europe, male and female percentages roughly the same due to loss of jobs in the exclusively male building sector ${ }^{21}$. For migrants in Ireland, what have the consequences of the recession been ${ }^{22}$ ? Women have been victims of job losses later and less than men $^{23}$, but migrants in general have always been hit harder, especially Eastern Europeans ${ }^{24}$, whose current situation is increasingly tough ${ }^{25}$. Ireland as a country has no monopoly on tensions accompanying rapid massive immigration; yet, a Behaviour \& Attitudes Survey made in $2007^{26}$ showed that two thirds of Irish women polled felt that 
"there (are) far too many immigrants coming into the country ${ }^{27 "}$. The same survey outlined a change in Irish women's mentalities: priorities are financial independence through paid employment, equality between the sexes, as well as personal care. This is illustrated through the emerging class divide between a category of middle-class Irish women and female migrants to whom they hand over caring roles to fulfil professional ambitions and have time to themselves. Nonetheless blaming some well-off women for exploiting others in the low-income category is a "gendered allegation" from a feminist point of view. Men and women alike are accountable in households that hire domestic workers ${ }^{28}$.

\section{Women in the Irish and the black economy}

What establishes similarities between all women of Ireland, be it in times of economic boom or recession, is their limited number at decision-making levels in different areas of society. EU-10 migrants have had jobs below their qualifications since their arrival, often as shop assistants, waiting staff in the retail or hospitality sectors and healthcare workers ${ }^{29}$. To a large extent, a parallel can be drawn between the situation of Polish and other migrants, and that of Irish women. Their number with third-level qualifications exceeds men's by far; yet, their very limited presence in top jobs has been repeatedly underlined in research papers ${ }^{30}$. Studies point at persisting job segregation ${ }^{31}$, with women being employed in just a few sectors. Official reports also emphasize that "women are under-represented in decision-making structures at both national and

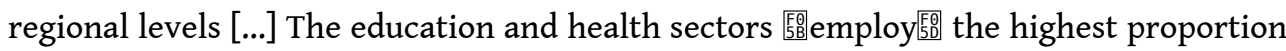
of women with around an $80 \%$ share of the total at work in these sectors. However women 皆are榴 not well represented at senior level positions ${ }^{32}$ ". In terms of wages, gender inequality persists and is bigger in the private than in the public sector ${ }^{33}$. Also, Irish employees are better paid than migrants, the hourly earnings of EU-10 migrants being the lowest. In 2007, when the economy was still doing well, hourly earnings of Irish nationals were $€ 20.64$, those of non-nationals $€ 18.04$, while EU accession states employees earned $€ 12.77$ per hour, $63.6 \%$ of the overall average hourly earnings of $€ 20.08$. Those employees also worked the longest, 37.6 hours per week in comparison with 34.2 hours for Irish employees ${ }^{34}$. In 2007, female migrants from EU accession states had the lowest mean hourly earnings ${ }^{35}$.

While all women are confronted with gender-based vertical and horizontal segregation, migrant women face another layer of disadvantage on account of their origin, and race $^{36}$, which pushes them further down the job ladder ${ }^{37}$. The sex industry is a case in point $^{38}$. Jane Freedman's research paper "Selling Sex: trafficking, Prostitution and Sex Work amongst Migrant Women in Europe" documents this issue and how it is linked with gender inequalities between and within countries, at the European and global levels ${ }^{39}$. Such illegal activities have lately developed in flats through escort agencies advertised on the Internet that have multiplied ${ }^{40}$ in the last decade and provide respectable façades for the sex industry. Migrant women are caught up in this new form of prostitution ${ }^{41}$, but this is difficult to document in quantitative terms prostitution and sex work being linked with trafficking ${ }^{42}$ and migration at the level of the European Union ${ }^{43}$. Jane Freedman wonders, in particular, to what extent separating women victims of trafficking from others who sell sex willingly is really relevant, since this distinction ignores the complexity of those migrants' motives and the different 
pressures they undergo. According to Freedman, gender inequalities and women's status in society are at the root of the problem. She quotes figures showing 120,000 women trafficked each year into and within Europe, a number given by the European Commission about ten years ago, to 300,000 according to the International Organization for Migration. A recent Irish report mentions 100 women trafficked in less than two years ${ }^{44}$, and a press article 1,000 women working in brothels every day ${ }^{45}$. In the view of European figures, such data appear plausible. The proportion of migrants among the overall number of sex workers is $60 \%$ in Holland, and between 50 and $70 \%$ in Germany ${ }^{46}$. An article from the Irish Times indicates a higher proportion of between 87 and $97 \%$ of migrant sex workers in Ireland in $2009^{47}$.

\section{"The road map to the stone age"}

8 Legislation targeting female migrants was implemented before the recession triggered the adoption of measures affecting the interests of women in general as part of the austerity plan. The June 2004 Citizenship Referendum ${ }^{48}$ was meant to reform jus soli ${ }^{49}$, thought to threaten the "integrity of Irish citizenship" at a time when pregnant foreign women were suspected of coming to Ireland only to give birth to babies that would be granted Irish citizenship and allowing their mothers to stay in the country. This triggered debates that were "not only racialized but also profoundly gendered ${ }^{50}$ ", according to Ronit Lentin ${ }^{51}$. This reform was approved of by nearly $80 \%$ of voters.

Ireland's ambivalent attitude towards EU migrants was illustrated from the start: an open-door policy in favour of employment ${ }^{52}$ was adopted at the same time as a series of measures against welfare tourism in $2004^{53}$. As regards nationals from the 2007 accession states, i.e. Romanians and Bulgarians ${ }^{54}$, restrictions concerning employment access through work permits were enforced ${ }^{55}$, although high-skilled professional categories were not concerned. In January 2009, due to the recession, more limits were introduced through a list of job categories for which getting a work permit or a green card was not allowed ${ }^{56}$. Potential health care migrants have been hit since this sector of employment is on the list.

Cuts in funding in the years before the actual financial collapse, together with the austerity plan adopted to face the economic crisis, have had negative consequences on women's situation in the public and private spheres. Public money going to support agencies, services, and women's organizations was withdrawn. As early as October 2008, the Equality Authority and the Combat the Poverty Agency faced budget cuts ${ }^{57}$. The National Women's Council of Ireland (NWCI), which promotes and implements equality programmes ${ }^{58}$, saw its budget fall sharply ${ }^{59}$. Funds have been axed. A case in point is the Equality for Women Measure, necessary for local women's groups to keep going ${ }^{60}$. The Community Platform was sidelined in 2004 for not approving of government poverty and equality policies. This affected the socially vulnerable even before recession ${ }^{61}$.

11 Support services destined for women victims of domestic violence disappeared or faced drastic cuts. The National Domestic Violence Intervention Agency (NDVIA) set up in 2003 had to close down in January $2007^{62}$. The budget of the National Office for the Prevention of Domestic, Sexual and Gender-Based Violence (COSC) was slashed ${ }^{6}$, like government funding for the Dublin Rape Crisis Centre, reduced year after year. SAFE Ireland ${ }^{64}$, a national organization coordinating frontline domestic violence services 
providers, was affected by severe cuts too. The NWCI, the mouthpiece of women's organizations, expressed its indignation emphasizing that a cause and effect relationship had been established between the rise in demand for services on domestic violence and the recession ${ }^{65}$.

Female migrants are twice victims of these anti-social measures, as women, and also as foreigners whose access to these services depends on the Habitual Residency Condition ${ }^{66}$. Besides, some refuges are reserved for Irish women ${ }^{67}$. Not only were specific support services for migrants hit, but the Human Rights Commission also faced cuts $^{68}$. As for the National Consultative Committee on Racism and Interculturalism (NCCRI), it was done away with altogether, which put an end to its research work ${ }^{69}$.

Surveys on homeless migrants show that a growing proportion of EU citizens used services or were sleeping rough between 2005 and 2008, most of them men. While sources do not provide a men/women breakdown, they insist that homelessness among all migrants can become a trap because of multiple disadvantages ${ }^{70}$. In short, female homelessness in general shows connections with social issues specific to women, domestic violence and single parenthood. There is another layer of difficulties resulting from cultural barriers in the case of female migrants. Reinforced repatriation policy has further illustrated Ireland's tough line ${ }^{71}$ : destitute migrants, who are refused social welfare, have been flown home since 2008, among them hundreds of EU nationals ${ }^{72}$. The Immigration, Residence and Protection Bill 2008, which has not been enacted so far, will allow the deportation of migrants deemed "unlawfully present", among them women who have become undocumented ${ }^{73}$.

Vulnerable female social categories such as low-earners ${ }^{74}$ and pensioners, beneficiaries of a series of "family" welfare payments such as child benefits, welfare payments to carers, and Christmas payment (altogether eliminated) have been targeted by budget austerity. Reduced eligibility for the medical card ${ }^{75}$, the cut of social welfare payments for people of working age without a job, have targeted already weakened female categories. Women, as a majority of employees in the public sector, have been affected by significant pay cuts $^{76}$, even though some consider that "public sector pay had got out of line during the boom ${ }^{77}$ ". The situation of women earning the minimum wage, which concerned migrants in the hospitality sector for example, threatened to get more difficult with the previous government's decision to reduce the hourly rate by one euro $^{78}$. This has been changed back by the new Fine Gael-Labour coalition government.

In the context of the budget cuts in November 2010, the bitter metaphor "road map to the stone age" was used by SIPTU President Jack O'Connor to describe the National Recovery Plan, which, according to him, would "deepen the recession ${ }^{79 "}$. Yet, the austerity plan has triggered contrasted analyses: the NWCI speaks of "the disempowerment of women ${ }^{80}$ ", when The Economic and Social Review put forward the idea that cuts would not increase social inequities in January $2010^{81}$. This statement may not deny the harsh social effects of the plan ${ }^{82}$; still, one cannot but find it overly optimistic. Indeed, the percentage of deprived people rose straight from the beginning of the depression, as did the percentage of people in consistent poverty. Lone parents households, almost always lone mothers, form the social category with the highest percentage of persons in consistent poverty ${ }^{83}$.

16 While the government has prioritized rigid budget reductions in spite of their social consequences, support initiatives and networks have developed to help deprived people, and more particularly women, weather the crisis. 


\section{The Limits of solidarity} nationals looking for jobs looming ${ }^{84}$. The QNHS published in June 2010 shows that female unemployment increased by $17 \%$ between June 2009 and June 2010, as compared with 3,5\% male employment. Data about job sectors with a majority of women show large declines in employment during the previous 12 months, a $17 \%$ decrease in the "accommodation and food service activities sector", while the wholesale and retail trade has been severely affected too ${ }^{85}$.

The recession has also had repercussions on matters of concern to women on a personal basis. In a period of financial hardship, the abortion issue shows similarities with a catch-22 situation for those who now live precariously in Ireland. While financial concerns may motivate a termination ${ }^{86}$, the cost appears too high to be met. On the other hand, among the women who can afford it, that is to say those who might otherwise have focussed on their careers, sources suggest that some now tend to seek stability in motherhood and traditional family values. The results of census 2011 show a higher annual number of births than the previous census in $2006^{87}$. The idea that women may fall back on family values is expanded on in an article dating from September $2010^{88}$. Women thinking of having a baby who find themselves unemployed or whose earnings are reduced may think it is now the time to take the plunge, because the "opportunity cost" of a baby is considerably lowered, an economic expression that refers to the loss of potential gain from other alternatives when one alternative is chosen.

In a period of economic downturn, the necessity to improve the way disadvantaged groups are given support or priority ${ }^{89}$ gets more urgent. Thus, the Equality and Rights Alliance (ERA) ${ }^{90}$ was created in August 2008 to protest against budget cuts affecting government funded equality and human rights agencies ${ }^{91}$ that were announced for 2009. Likewise, the NWCI has strived to develop partnerships with independent bodies to increase its clout as regards women's issues, through its current Submission to the Equality Authority on the Strategic Plan 2011-2014 ${ }^{92}$ for example. The NWCI federates about 160 organizations, groups as well as networks bringing together various women's and migrants' organizations. The NWCI gives us a map of female communities throughout the 26 counties, yet the integration of socially or culturally diverse groups into the society is beyond its scope and remit. The NWCI took a public stance in favour of citizenship rights based on jus soli, advocating a no-vote in the 2004 referendum, but the landslide victory of the yes-vote reflected the poor influence exerted by the NWCI on the female electorate on that occasion.

One may also wonder to what extent female migrants find support for issues of concern to them as women through migrants' organizations themselves: the specific directory of migrants' organizations shows that a vast majority have men as leaders or persons in charge. Only five out of over sixty are actual women's organizations, which may raise questions about female migrants' autonomy. This can hinder their visibility in society as well as increase the difficulty in reaching out to them to tackle specific issues. To deal with such questions, women's organizations for migrants have emerged. Dublinbased AkiDwa, founded in 2001 by African women, now defends all female migrants' rights $^{93}$. Although attendance to its meetings still reflects a communal tendency, 
Eastern European migrants' presence is increasing. AkiDwa focuses on domestic workers' and nurses' issues ${ }^{94}$, and is currently developing a programme, funded by the Government and the EU, the "Door to work programme", to help all migrant women find employment through performing voluntary work as a foothold to a paid job. Such a programme appears as the last hope for many when the risk of being victims of discrimination ${ }^{95}$ has increased for migrants during the recession. Female migrant organizations, like the Tralee International Women's Resource Centre in County Kerry, have been created elsewhere.

21 To deal with red tape, migrants get help from Irish bodies like the Migrants Rights Centre $^{96}$ and the Irish Refugee Council ${ }^{97}$. The independent Immigrant Council of Ireland, established in $2001^{98}$, has developed collaboration with Women's aid ${ }^{99}$ and hosted a seminar in 2006 about male violence ${ }^{100}$ in order to develop specific support to women. It published a report in 2009, together with the government's Women's Health Project ${ }^{101}$ and Ruhama ${ }^{102}$, an NGO helping the victims of sex trade. The "Turn-Off-The Red-Light Campaign ${ }^{103}$ ", launched by a group of Irish men in February 2011, aims at bringing the Irish legislation about prostitution in line with the Swedish legislation ${ }^{104}$. But migrants' empowerment depends mostly on their control of the English language. This issue was seen as particularly relevant to Polish migrants as early as $2006^{105}$. As cuts in funding devoted to education in general, to English language support in particular, have been imposed by government ${ }^{106}$, courses for migrants have been proposed by women's organizations ${ }^{107}$. In a more pragmatic way, the Irish Family Planning Association has issued on-line multilingual resources ${ }^{108}$.

Beyond the many support initiatives in favour of female migrants, the fundamental question of their integration arises ${ }^{109}$. To tackle this issue, a Junior Ministry for integration was created in 2007, but both its lack of funding and the new Ministry's limited remit were soon pointed out ${ }^{110}$. There may be solidarity through initiatives and programmes involving Irish persons working with migrants, while social links remain weak. According to a report published in 2008 by the ICI ${ }^{111}$, EU migrants do not fare better than those from outside the EU. Migrants talk of their experience of social isolation in the workplace ${ }^{112}$. The absence of family reunification policy for most categories of migrants ${ }^{113}$ makes living conditions harder to cope with. Those who live in rural areas feel particularly alienated from society as the effects of the downturn in rural Ireland seem even worse than in urban areas ${ }^{114}$. A $2010 \mathrm{EU}$-funded qualitative report, in partnership with the ICI, exposes lack of access to information, ignorance concerning the existence of equality bodies, and of anti-discrimination laws, by a large majority of central and Eastern European migrants ${ }^{115}$. "Beyond the issue of rights and liberal conceptions of equality, there remains the need to address institutional barriers caused by the inability of services to address difference ${ }^{116}$ ". Such a need has been even more crucial since 2007, when this statement was made.

The expression "women of Ireland" evokes women's status and role in society, as well as the interactions between Irish women and female migrants in Celtic Tiger and post Celtic Tiger Ireland. This calls forth terms used by academic Carmel Roulston, who describes the female landscape as global and fragmented in the post-feminist period ${ }^{117}$. Women in general experience discrimination that turns them into victims at different levels and in different ways in a patriarchal society ruled by a competitive and productive neoliberal system in which caring professions do not have pride of place. A new class divide has emerged between some middle-class Irish women and the 
migrants they recruit as home carers. While detailed data about employment with a men/women breakdown along nationality lines is not available ${ }^{118}$, the recession has affected female migrants working in job sectors such as the hospitality or the retail sectors. Unemployment, pay cuts and cuts in benefits have affected women in general. The sharp reduction of funding for equality and community programmes has not helped solidarity. The segregated structure of women's pressure groups and organizations does not favour interaction between Irish and foreign nationals. In Ireland, the latter are discriminated against both as women and as members of an ethnic minority group. While recent economic research says that social inequities in general have not increased as a result of the austerity measures, this raises doubt considering that the number of people in consistent poverty has increased, women representing a majority of this category of people. One can fear that in times when social justice ${ }^{119}$ and equality do not progress, they may in fact regress, as targeted policies are indispensable to fight against inequities. This is even more necessary in harsh times since women hit by job cuts, or a deterioration of their working conditions, may fall back on their traditional role as mothers and homemakers. Inequalities can only grow, while the full impact of neoliberal austerity measures on all women, both in their professional and family lives, will only be assessed in the long run.

\section{NOTES}

1. This metaphor refers to the unprecedented boom of the Irish economy between the mid-1990s and the downturn in 2002, followed by the 2008 financial crisis and the burst of the Irish Housing sector.

2. Cyprus, the Czech Republic, Estonia Hungary, Latvia, Lithuania, Malta, Poland, Slovenia and Slovakia joined in 2004. "EU-10 nationals" refers to citizens from those 10 new member-states in this essay. "EU-12 nationals" refers to "EU 10 nationals" together with nationals from Romania and Bulgaria, the two states that joined the EU in 2007. The terminology EU-10 and EU-12 is used in the Annual Monitoring Report on Integration 2010, ESRI, Dublin, April 2011, p. 5. Martin Ruhs (COMPAS), Emma Quinn (ESRI), "From Rapid Immigration to "Recession", Migration Policy Institute, Sept. 2009, 14p, p. 1-4.

3. Wording used in Annual Monitoring Report on Integration 2010, ESRI, Dublin, May 2011, p. 6.

4. Women represented around $80 \%$ of employees in education and health in 2005 , Men and Women in Ireland 2005, press release, 16 Dec. 2005. Women and men in Ireland 2009, CSO, Dublin, February 2010, p. 11. The Irish Times, 2 Feb. 2011, p. 5.

5. Helma Lutz, editor, Migration and Domestic Work, Ashgate, 2008, p. 1.

6. Joy M. Zarembka, in Global Woman, Granta Books, London, 203, p. 143-153.

7. The Irish Times, 19 Dec. 2001. Women and Men in Ireland 2008, Central Statistics Office 2008, Dublin, April 2009, table 2.3, p. 24. 
8. The Irish Times, 4 March 2000.

9. The Irish. Times, 8 Nov. 2005.

10. The Irish Times, 28 Apr. 2010.

11. Helen Stalford et alii, eds, Gender and Migration in 21st Century Europe, Ashgate, 2009, p. 45-60.

12. Martha Doyle, Virpi Timonen, "The different faces of care work: understanding the experiences of the multi-cultural care workforce", In Ageing and Society, CUP, 2009, p. 338.

13. Tony Fahey et. alii, editors, Best of Times? The Social Impact of the Celtic Tiger, IPA, Dublin, 2007, p. 230.

14. Alan Barrett, Anna Rust, "Projecting the Future Numbers of Migrant Workers in the Health and Social Care Sectors in Ireland", ESRI, Working paper No. 275, Jan. 2009, p. 10.

15. The Irish Times, 25 Sept. 2009.

16. The Irish. Times, 25 Sept. 2009.

17. The Irish Times, 7 May 2010.

18. Non-nationals represented just over $7,5 \%$ of the population in $2004,14 \%$ at the end of 2007. Their numbers then declined. Figures, based on CSO Quarterly National Household Surveys, quoted in Alan Barrett, Elish Kelly, "The Impact of Ireland's Recession on the Labour Market Outcomes of its Immigrants", Institute for the Study of Labour, Bonn, Germany, Sept. 2010, p. 3-4. Immigrants represented about 10\% of the population in 2006. In the 12 months preceding census day in 2006, over 121,000 arrived, 45\% were Irish born. Among non- nationals, there were over 35,000 Polish, over 22,000 UK migrants, nearly 7,500 Lithuanians. Statistical Yearbook 2010, p. 5. According to Census 2006 the men/female migrant breakdown was $53 \%$ to 4 . Nearly $65 \%$ of Polish migrants were men: figures quoted in Steven Loyal, "Migrants and Migration in Ireland: Adjusting to a New Reality”, in Demetrios G. et alii, 2010, p. 83.

19. Tony Fahey, op. cit., p. 233.

20. Grainne O'Keeffe-Vigneron, « Les Irlandais en Angleterre et les polonais en Irlande : chemins convergents ou parcours divergents?", in Lucienne Germain et alii, L'Harmattan 2010, p. 169-185.

21. Ursula Barry, Short report on migrant women in Ireland, UCD School of Social Justice Working Papers Series, Oct. 2010, p. 2.

22. The Irish Times, 17 July 2008.

23. QNHS, Quarter 4 2007, CSO, Dublin, 2008, p. 3. QNHS Quarter 2, Sept 2010, p. 2. No men/women breakdown provided.

24. Alan Barrett, Elish Kelly, “The Impact of Ireland's Recession on the Labour Market Outcomes of its Immigrants", p. 11 \& 20-21.

25. Over $11 \%$ of female migrants unemployed in 2009 , less than $8 \%$ Irish women, their employment rate in 2009 was below Irish women's. Annual Monitoring Report on Integration 2010, p. 6 \&17.

26. Behaviour and Attitudes, Milltown House, Milltown, Dublin 6. [

$\underline{w w w . b a n d a . i e}$

].

Études irlandaises, 37-2 | 2012 
27. The Irish Times, 29 Sept. 2007.

28. Kathleen Lynch and Maureen Lyons, "The Gendered Order of Caring", in Where are we Now?, Ursula Barry ed., Dublin, 2008, p. 178.

29. The Irish Times, 25 Apr. 2007. Alan Barrett, Anna Rust, "Projecting the Future Numbers of Migrant Workers in the Health and Social Care Sectors in Ireland", p. 5-7.

30. $51 \%$ women with third level qualifications in $2009,39 \%$ men Women and Men in Ireland 2010, CSO, press release: [

http://www.cso.ie/newsevents/pr_womenandmen2010.htm ], accessed on 04/02/2011. Women and Men in Ireland 2009, Dublin, Feb. 2010, p. 10.

31. 63\% of Irish women are still located in just five occupational categories; Helen Russell et alii, “A Woman's Place; Female Participation in the Irish Labour Market”, The Equality Authority and ESRI, Dublin, 2009, p. 13.

32. Press release, Women and Men In Ireland 2007, [

http://www.cso.ie/newsevents/pr_womenandmen2007.htm

], accessed on 04/02/2011. Women and Men In Ireland 2008, CSO, Dublin, 2009, p. 10.

33. National Employment Survey 2007, CSO, Dublin, July 2009, p. 9.

34. National Employment Survey 2007, p. 13.

35. In 2004 and 2007, accession states female migrants earned $€ 11.50$ hourly, compared with $€ 19.42$ for Irish women and 16.68 for other EU migrants. N.E.S. 2007, p. 44.

36. Jane Pillinger, The Feminization of Migration, Experiences and Opportunities in Ireland, ICI, Dublin, 2007, p. 2.

37. Helen Russell, “A Woman's Place. Female Participation in the Irish Labour Market”, p. 12.

38. The Irish Times, 30 August 2010.

39. Jane Freedman, “Selling Sex", in Gender and Insecurity, Ashgate, 2003, p. 122.

40. The Irish Times, Week End Review, 8-10 May 2010.

41. Monica O'Connor, Jane Pillinger, “Globalisation, Sex trafficking and Prostitution; the Experience of Migrant women in Ireland", ICI, The Women's Health Project and Ruhama, Dublin, 2009, p. 55.

42. The Irish Times, 6 May 2006. The Criminal Law (Human Trafficking) Act 2008 is a prevention measure against trafficking for prostitution.

43. Jane Freedman “Selling Sex”, op. cit., p. 120-121. The Independent, 28 January 2007.

44. Monica O'Connor, Jane Pillinger, op. cit., p. 55.

45. The Irish Times, 16 April 2009.

46. Jane Freedman, op. cit., p. 128.

47. The Irish Times, 16 April 2009 and 17 April 2009, based on the O'Connor and Pillinger 2009 Report on Sex Trafficking and Prostitution; see note 29.

48. Bairbre Ni Chiosain, "Passports for the New Irish? The 2004 Citizenship Referendum", Études Irlandaises, automne 2007, n³2.2, p. 31-47.

49. Jus soli, ie. citizenship by birth (1935 Irish Nationality and Citizenship Act). 
50. The Irish Times, 21 May 2004; Bryan Fanning “Integration and social Policy" in Immigration and social change in the Republic of Ireland, Manchester University Press, 2007, p. 245.

51. Ronit Lentin, Trinity College Dublin, “Migrant Women's Networking: New articulations of transnational ethnicity", not dated, $19 \mathrm{p}$.

52. Employment Permits Bill 2003 granted workers from the $10 \mathrm{EU}$ accession states free access to the Irish labour market as from May 1, 2004.

53. Best of Times, p. 229. In March 2004 a two-year condition was placed: to be able to claim child benefits and social assistance, EU migrants had to meet strict requirements.

54. Nationals from the two states that joined the EU in 2007, Bulgaria and Romania, referred to as EU12 nationals, see note 1 p. 1.

55. Ruhs \& Quinn, op. cit., p. 9.

56. Barry, op. cit., p. 6.

57. Irish Times, 9 July 2009.

58. This refers to jobseeker allowance, pensions, and family income supplement in particular, NWCI, Pre-budget submission. 2011, Sept. 2010, p. 7-8.

59. NWCI 2007, 2008 and 2009 Annual reports. [

http://www.nwci.ie

] accessed on 2.05.2011.

60. NWCI Annual Report 2008, p. 7. NWCI, “ Response to the McCarthy Report”.

61. The Irish Times, 19 July 2004.

62. [

http://www.irishhealth.com/article.html?id=10925

] accessed on 4.05.2011.

63. NWCI, "Response to the McCarthy Report", September 2009, p. 7. Patrick Smyth, "Sisters", The Irish Times, 26 May 2010.

64. Jacinta Carey, Chairperson, Safe Ireland, e-mail message, 20.04.2011.

65. NWCI 2009 Annual Report, not dated, p. 13-14.

66. Steven Loyal, “ Migrants and Migration in Ireland: Adjusting to a New Reality”, p. 9.

67. The Irish Times, 25 Sept. 2010.

68. Irish Human Rights Commission, submission to the UN CERD Committee on the examination of Ireland's combined 3rd and 4th reports, Nov. 2010, p. 7-43.

69. Steven Loyal, op. cit., p. 91.

70. There were $10 \%$ of EU citizens among the homeless in 2008 , especially from the UK, Poland and Romania. Counted In, 2008, p. 23, 52, 69-70.

71. [

http://www.ria.gov.ie

] acc. on 10 April 2012.

72. The Irish Times, 5 March 2011.

73. Barry, op. cit., p. 7.

74. Irish Examiner, 25 Nov. 2010: the tax net now opens at $€ 15,300$, compared to $€ 18,300$ previously. 
75. The medical card entitles low earners or people without a job to get free health care.

76. $90 \%$ of the 2009 graduates emigrated or considered emigrating at the time, The Irish Times, 15 December 2009.

77. ESR, Winter 2010, p. 467.

78. The Independent, 8 March 2011.

79. Irish Examiner, 25 Nov. 2010.

80. NWCI, "Response to the McCarthy Report", p. 16.

81. Tim Callan, et alii, The Economic and Social Review, Vol.41, Winter 2010, p. 461-471.

82. Qualitative research was done for this paper. Questionnaire to Irish women of different age and socioeconomic categories: out of 11 who replied, 10 expressed strong concern about their current personal and family situation, fear of the future even.

83. Survey on Income and Living Conditions (SILC) 2009, CSO, Dublin, Nov. 2010, p. 3.

84. The Irish Times, 10 February 2011 and 12 March 2011.

85. QNHS, 16 June 2011, p. 1-3 \& 14.

86. In 15 to $20 \%$ of the cases dealt with by the DWWC in 2009, The Irish Times, 28 June 2010 and 17 December 2010.

87. [

www.cso.ie/en/media/csoie/census/documents/census2011pdf/

], accessed on 9 April 2012. CSO Vital Statistics, $1^{\text {st }}$ Quarter 2010, October 2010, p. 4. CSO Vital Statistics, 2nd Quarter 2009, press release.

88. "No real dip in birth rate as people seek solace in babies", The Irish Times, 23 September 2010.

89. Steven Loyal, op. cit., p. 81-94.

90. ERA created in Aug. 2008, gathers an increasing number of civil society groups, about 50 in February 2011.

[

http://Irishlawblog.blogspot.com/2009/01/vacancy-equality-and-rights-alliance.html

].

91. The Irish Times, 16 Sept. 2008.

92. NWCI, Submission to Equality Authority, May 2011, 9 p.

93. In AkiDwa's 2009 booklet "Past Present and Future", the four titles of publications listed for the period of time 2003 to 2008 focus on African women's issues.

94. Lentin, op. cit., p. 13-14.

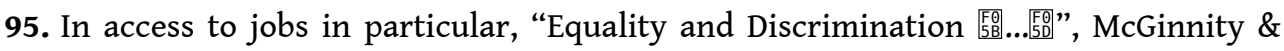
Russell, ESRI Res. Bull.,1.01 2011.

96. [

http://www.mrci.ie/Our-Work/

] accessed on 14 May 2011.

97. [

$\underline{w w w . i r i s h r e f u g e e c o u n c i l . i e}$

] accessed on 14 May 2011. 
98. [http://

www.immigrantcouncil.ie/about-us/background

] accessed on 14 May 2011.

99. An Irish organisation dealing with domestic violence.

100. "Addressing the needs of Black and Minority Ethnic Women Experiencing Male Violence", A Seminar Hosted by AkiDwA, The Immigrant Council of Ireland and Women's Aid, 2006.

101. [

http://www.hse.ie/eng/services/Find_a_Service/Sexulahealth/Women'sHealth_Project/ ].

102. [

http://www.ruhama.ie/page.php?inPageID=4

].

103. The Irish Times, 1 March 2011. [

http://www.turnofftheredlight.ie

].

104. The Irish Times, 8 Feb. 2011.

105. The Irish Times, 16 Nov. 2006.

106. The Irish Times, 7 Feb. 2011.

107. AkiDwa's Open and Information Day, 15 April 2011, Dublin. Participants have to leave a deposit at the beginning of the classes; regular attendance allows them to get it back at the end. [

http://www.kaplaninternational.com/schools/ireland/learn-english.aspx ].

108. IFPA, "Sexual Health Asylum", Dublin, not dated, list of multilingual resources, p. 33.

109. Feldman, Alice and Gilmartin, Mary and Loyal, Steven and Migge, Bettina, Getting On: From Migration to Integration - Chinese, Indian, Lithuanian and Nigerian Migrants' Experiences in Ireland, Immigrant Council of Ireland, Dublin, 2008, p. 10-11.

110. Ibid., p. 22.

111. Ibid., p. $20 \& 180$.

112. Jane Pillinger, op. cit., p. 2.

113. Ursula Barry, op. cit., p. 6-8.

114. The Irish Times, 4 March 2009.

115. The Irish Times, 8 May 2010.

116. Bryan Fanning, op. cit., p. 254.

117. Carmel Roulston, "Feminism, Politics and Postmodernism", in Contesting Politics, Westview Press, Oxford, 1999, p. 4.

118. Annual Monitoring Report on Integration, 2010, p. 7.

119. Organisation for Economic Cooperation and Development. The Irish Times, 4 Jan. 2011. 


\section{ABSTRACTS}

Economic prosperity during the Celtic Tiger stimulated the development of the job market, and drew migrants to Ireland especially from EU countries. Relationships between Irishwomen and female migrants in employment sectors reflected new social tensions and inequalities, both in the public and in the private spheres.

La prospérité économique durant le Tigre celtique a stimulé le marché de l'emploi, ainsi que l'immigration, en provenance de l'union européenne surtout. Les relations entre les Irlandaises et les immigrantes au travail illustrent de nouvelles formes d'inégalités, à la fois dans la sphère privée et dans la sphère publique.

\section{INDEX}

Mots-clés: femmes, immigration, débat public, Irlande - questions économiques et sociales

Keywords: women, immigration, Ireland - socio-economic issues, public debate, European Union / EEC

\section{AUTHOR}

\section{MARIE-JEANNE DA COL RICHERT}

Université de Strasbourg 